\title{
MUSSELS WITH MEAT: BIVALVE TISSUE-SHELL RADIOCARBON AGE DIFFERENCES AND ARCHAEOLOGICAL IMPLICATIONS
}

\author{
Ricardo Fernandes ${ }^{1,2,3}$ • Stefanie Bergemann ${ }^{2}$ - Sönke Hartz ${ }^{4}$ Pieter M Grootes ${ }^{1,2}$ • \\ Marie-Josée Nadeau ${ }^{1,2} \cdot$ Frank Melzner $^{5} \cdot$ Andrzej Rakowski $^{1} \bullet$ Matthias Hüls $^{1}$
}

\begin{abstract}
Local reservoir ages are often estimated from the difference between the radiocarbon ages of aquatic material and associated terrestrial samples for which no reservoir effect is expected. Frequently, the selected aquatic material consists of bivalve shells that are typically well preserved in the archaeological record. For instance, large shell middens attest to the importance of mussel consumption at both coastal and inland sites. However, different physiological mechanisms associated with tissue and shell growth may result in differences in reservoir effects between the surviving component (shell) and the component relevant to dietary reservoir effects in consumers (tissue). The current study examines bivalve tissue-shell age differences both from freshwater and marine contexts close to archaeological sites where human consumption of mollusks has been attested. Results exhibited significant ${ }^{14} \mathrm{C}$ age differences between bivalve tissue and shell in a freshwater context. In a marine context, no significant bivalve tissue-shell age differences were observed. The results also showed that riverine and lacustrine shells show large and variable freshwater reservoir effects. The results have important implications for establishing local reservoir effects especially in a freshwater environment. For good a priori knowledge of expected ${ }^{14} \mathrm{C}$ differences in organic and inorganic water, carbon is thus necessary. Furthermore, the high variability in freshwater shell ${ }^{14} \mathrm{C}$ ages implies the need for representative sampling from the archaeological record.
\end{abstract}

\section{INTRODUCTION}

Radiocarbon dating is currently one of the main dating techniques used within archaeological research to establish absolute chronologies. The underlying assumption for the use of ${ }^{14} \mathrm{C}$ dating is that the ${ }^{14} \mathrm{C}$ level in the measured sample equaled, when corrected for fractionation, that of the contemporaneous atmosphere or atmospheric reservoir. This assumption is generally valid as atmospheric ${ }^{14} \mathrm{C}$ is well admixed and has a short residence time when compared to its half-life (Levin et al. 1980; Levin and Hesshaimer 2000). Most aquatic reservoirs are, however, ${ }^{14} \mathrm{C}$ depleted when compared with the atmospheric reservoir. Reservoir effect, defined as the ${ }^{14} \mathrm{C}$ age offset between the aquatic and atmospheric reservoir, is referred to as the marine reservoir effect (MRE) when considering the ocean, and the freshwater reservoir effect (FRE) for freshwater aquatic reservoirs (Ascough et al. 2004, 2007, 2010). The mechanisms underlying reservoir effects are varied. In a marine context, surface water reservoir age will depend on carbon mixing from atmospheric $\mathrm{CO}_{2}$ and on the upwelling of deeper waters containing carbon with long residence times. Marine surface reservoir ages will vary with coastal location and with time reflecting climatic variations, oceanic circulation patterns, depths of source water, and coastal, topography (Gordon and Harkness 1992; Ascough et al. 2004). A MRE reference value, or global marine reservoir effect, of $400 \mathrm{yr}$ is corrected for local variations both in time and space. Freshwater reservoir effects present a large local variability, and may reach much larger ${ }^{14} \mathrm{C}$ offsets than marine reservoirs, often of several thousands of years (Geyh et al. 1998; Geyh 2000; Hall and Henderson 2001; Zhou et al. 2009; Ascough et al. 2010). Causes for FRE include long residence times of groundwater, dissolved carbonates originating from the geological background, oxidation of old organic matter and sediments, and glacier meltdown (Olsson 1980; Landmeyer and Stone 1995; Lanting and van der Plicht 1998; Levin and Hesshaimer 2000; Geyh 2000; Hall and Henderson 2001; Ascough et al. 2010, 2011).

\footnotetext{
${ }^{1}$ Leibniz Laboratory for Radiometric Dating and Isotope Research, Kiel University, Kiel, Germany.

${ }^{2}$ Graduate School Human Development in Landscapes, Kiel University, Kiel, Germany.

${ }^{3}$ Corresponding author. Email: rfernandes@gshdl.uni-kiel.de.

${ }^{4}$ Stiftung Schleswig-Holsteinische Landesmuseen Schloss Gottorf, Schleswig, Germany.

${ }^{5}$ Helmholtz Centre for Ocean Research (GEOMAR), Department of Marine Ecology, Kiel, Germany.
}

(C) 2012 by the Arizona Board of Regents on behalf of the University of Arizona Proceedings of the 6th International Radiocarbon and Archaeology Symposium, edited by E Boaretto and N R Rebollo Franco RADIOCARBON, Vol 54, $\mathrm{Nr} 3-4,2012$, p 953-965 
Historical chronologies are often based on the ${ }^{14} \mathrm{C}$ dating of human remains. Reservoir effects can, however, be transferred to humans through the foodchain. Humans who consumed a significant quantity of protein from aquatic sources will also show a reservoir effect. Several known examples, both in marine and freshwater contexts, illustrate the presence of reservoir effects in ancient humans (Lanting and van der Plicht 1998; Cook et al. 2001; Yoneda et al. 2004; Culleton 2006; Fischer et al. 2007; Lillie et al. 2009; Naito et al. 2010; Olsen et al. 2010). Accurate archaeological chronologies require quantification of local reservoir effects, and these are frequently established by dating associated pairs of aquatic and terrestrial samples that are in spatial and temporal proximity of the archaeological material under study (Ascough et al. 2005). Ideally, such pairs would include remains of the aquatic species consumed. Consumed species could have been traded from different locations, and thus present different MRE or FRE values. Variations for the same species have also been observed as depending on the feeding location (Ascough et al. 2011).

Mollusks constitute a phylum (Mollusca) of invertebrate animals, which is divided into different classes. The present study focuses only on the class Bivalvia. Bivalve shells are of great importance in the study of reservoir effects within an archaeological context for 2 main reasons. First, there is extensive archaeological evidence of human consumption of bivalves in prehistoric periods, in a variety of contexts (Waselkov 1987; Balbo et al. 2011). Archaeological examples include the formation of shell middens by hunter-gatherers in Atlantic Europe from the Middle Paleolithic, with a large number of Mesolithic shell middens being documented (Gutiérrez-Zugasti et al. 2011). Other archaeological examples include the prehistoric Jomon period $(\sim 14,000-500 \mathrm{BC})$ in Japan (Habu et al. 2011), and hunter-gatherers in the southwestern Cape of South Africa (Smith et al. 1991; Jerardino 1998). Freshwater shell middens, though less frequent, have also been reported (e.g. Parmalee and Klippel 1974; Waselkov 1987; Roosevelt et al. 1991; Habu et al. 2011).

Secondly, bivalve shells from the archaeological record, faunal collections, or shells collected live are often used to establish local reservoir effects (e.g. Hogg and Higham 1998; Dumond and Griffin 2002; Ascough et al. 2005; Cage et al. 2006; Gillespie et al. 2009). Shell material survives better in most depositional settings than organic matter, or even fish bones.

The physiological mechanisms underlying bivalve tissue and shell synthesis are, however, very different (Amouroux 1984; Roditi et al. 2000; Vuorio et al. 2007; Poulain et al. 2010). Given that only bivalve tissue is consumed by humans, and that different ${ }^{14} \mathrm{C}$ signals may be expected for bivalve tissue or shell, the reliability of ${ }^{14} \mathrm{C}$ values in bivalve shells as a correction for human reservoir effects may be questioned. Moreover, mollusks are an integral part of the aquatic foodchain that includes other human-consumed species, e.g. trout (Arawomo 1980) or eel (Nie 1982). Differences in bivalve tissue ${ }^{14} \mathrm{C}$ ages will also introduce differentiated ${ }^{14} \mathrm{C}$ signals into higher trophic level species.

The aim of the present study was to undertake a first investigation into possible bivalve tissue-shell ${ }^{14} \mathrm{C}$ differences. The examined bivalve samples originated from freshwater, both riverine and lacustrine, and marine locations. Marine and riverine locations are located in the near or immediate vicinity of archaeological sites where consumption of bivalves by ancient populations is indicated by the presence of shell middens.

\section{MATERIALS AND METHODS}

\section{Material and Descriptive Background}

Seven live bivalve specimens (Figure 1) were collected in 2009 and early 2011 from 3 different locations (Table 1, Figure 2). In addition, paired shell and bone samples were obtained from the archaeological sites of Quern-Neukirchen and Zauschwitz, Germany (Figure 2). 


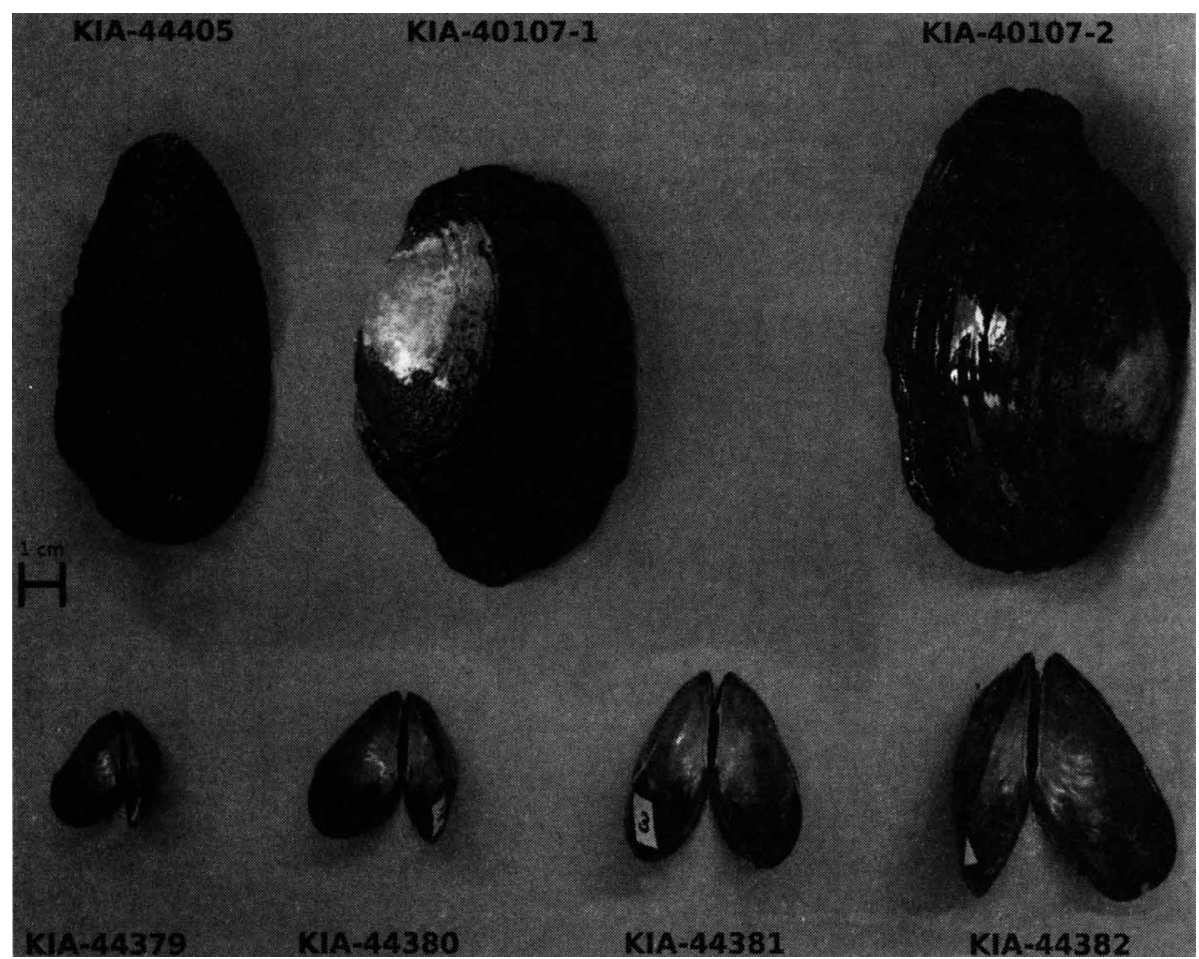

Figure 1 Collected bivalve specimens

Table 1 Collected live bivalve specimens.

\begin{tabular}{|c|c|c|c|c|c|c|c|}
\hline $\begin{array}{l}\text { Sample } \\
\text { ID }\end{array}$ & $\begin{array}{l}\text { Lab code } \\
\text { (tissue) }\end{array}$ & $\begin{array}{l}\text { Lab code } \\
\text { (shell) }\end{array}$ & Species & Location & $\begin{array}{l}\text { Collection } \\
\text { year } \\
\text { (AD) }\end{array}$ & $\begin{array}{l}\text { Age } \\
(\mathrm{yr})\end{array}$ & $\begin{array}{l}\text { Shell } \\
\text { length } \\
(\mathrm{mm})\end{array}$ \\
\hline K-01 & KIA-44379 & KIA-44383 & $\begin{array}{l}\text { Mytilus edu- } \\
\text { lis }\end{array}$ & Kiel Fjord & 2011 & $<5$ & 31 \\
\hline $\mathrm{K}-01$ & KIA-44380 & KIA-44384 & $\begin{array}{l}\text { Mytilus edu- } \\
\text { lis }\end{array}$ & Kiel Fjord & 2011 & $<5$ & 40 \\
\hline K-01 & KIA-44381 & KIA-44385 & $\begin{array}{l}\text { Mytilus edu- } \\
\text { lis }\end{array}$ & Kiel Fjord & 2011 & $<5$ & 50 \\
\hline $\mathrm{K}-01$ & KIA-44382 & KIA-44386 & $\begin{array}{l}\text { Mytilus edu- } \\
\text { lis }\end{array}$ & Kiel Fjord & 2011 & $<5$ & 59 \\
\hline Z-01 & KIA-40107-1 & KIA-40107-1 & $\begin{array}{l}\text { Anodonta } \\
\text { anatina }\end{array}$ & $\begin{array}{l}\text { Weiße Elster } \\
\text { River }\end{array}$ & 2009 & $5-6$ & 94 \\
\hline Z-02 & KIA-40107-2 & KIA-40107-2 & $\begin{array}{l}\text { Anodonta } \\
\text { anatina }\end{array}$ & $\begin{array}{l}\text { Weiße Elster } \\
\text { River }\end{array}$ & 2009 & $5-6$ & 108 \\
\hline $\mathrm{R}-01$ & KIA-44405 & KIA-44404 & Unio tumidus & Lake Rosenfeld & 2010 & $5-6$ & 84 \\
\hline
\end{tabular}

Quern-Neukirchen is located $\sim 2 \mathrm{~km}$ east of the village of Nieby and $\sim 200 \mathrm{~m}$ from the present Baltic Sea coastline. A few pottery shards and some surface retouched tools assigned the site to the Late Neolithic period, in northern Germany known under the term Dolchzeit ( 2200-1700 cal BC). Waterlogged finds were found partly embedded in a shell midden, one of the very rare examples on the Baltic coast of northern Germany and southern Scandinavia that provides good organic preservation. 


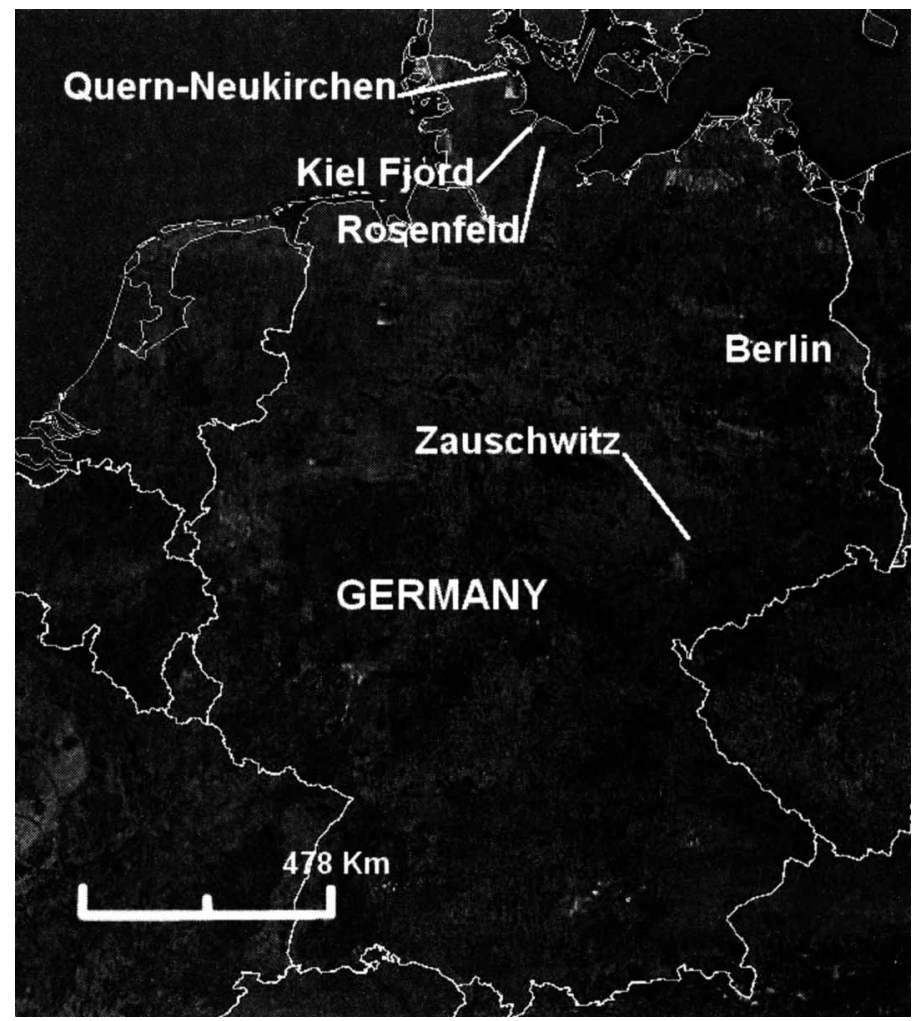

Figure 2 Location of the studied archaeological sites of Quern-Neukirchen and Zauschwitz, and the collection sites of live bivalve specimens at Kiel Fjord. Lake Rosenfeld, and the Weiße Elster River in the immediate vicinity of Zauschwitz. Map image adapted from Google Earth (C) 2010 Google.

The site's chronology was established through ${ }^{14} \mathrm{C}$ dating, assigning the settlement occupation to $\sim 2000-1800$ cal BC. ${ }^{14} \mathrm{C}$ dates include 2 contextually associated pairs of animal-mollusk samples (Table 2). The ${ }^{14} \mathrm{C}$ age offsets between the animal collagen ${ }^{14} \mathrm{C}$ date and carbonate mussel shell indicate an average reservoir age of $560 \mathrm{yr}$.

Table 2 Conventional ${ }^{14} \mathrm{C}$ dates on associated terrestrial/aquatic samples from Quern-Neukirchen.

\begin{tabular}{llll}
\hline Terrestrial sample & $\begin{array}{l}\text { Conventional age } \\
\text { (yr BP) }\end{array}$ & Aquatic sample & $\begin{array}{l}\text { Conventional age } \\
\text { (yr BP) }\end{array}$ \\
\hline $\begin{array}{l}\text { Collagen (unidentified animal) } \\
\text { (KIA-43919) }\end{array}$ & $3660 \pm 30$ & $\begin{array}{l}\text { Mollusk shell } \\
\text { (KIA-43951) }\end{array}$ & $4210 \pm 30$ \\
$\begin{array}{l}\text { Collagen (red deer antlers) } \\
\text { (KIA-43920) }\end{array}$ & $3650 \pm 25$ & $\begin{array}{l}\text { Mollusk shell } \\
\text { (KIA-43952) }\end{array}$ & $4220 \pm 30$ \\
\hline
\end{tabular}

Kiel Fjord is located $\sim 50 \mathrm{~km}$ to the southeast of Quern-Neukirchen, with both locations bordering Kiel Bay (Baltic Sea). The Baltic Sea is brackish, receiving significant water input from the North Sea and from freshwater terrestrial sources, and having a relatively low evaporation (Kallio 2006). The approximate shape of the present-day Baltic Sea, with its limited access to the North Sea, originated $\sim 7000 \mathrm{yr}$ ago and it followed the formation of the Littorina Sea, which was itself formed by the rapid sea rise resulting from retreating ice covers (Kallio 2006; Schmölcke et al. 2006). Four live 
specimens of Mytilus edulis (K-01 to K-04) of varied shell lengths and $<5 \mathrm{yr}$ of age were collected from the Kiel Fjord (Table 1). The bivalve species Mytilus edulis, commonly known as blue mussel, is a widely distributed species commonly harvested for human food consumption, and often found within archaeological contexts (Gutiérrez-Zugasti et al. 2011).

Zauschwitz is located on the west bank of the Weiße Elster River in northwest Saxony and is a known archaeological site since the second half of the 19th century. Occupation phases from early Neolithic linear pottery culture up to high Medieval times were established for this site. Middle Neolithic Salzmünde features are the earliest that contain significant amounts of mollusk shells. In one of these features, about 10,000 mollusk shells (Coblenz and Fritzsche 1980) were found. A skeleton of a human infant was placed over a thick layer of crushed mollusk shells and under at least 2 further layers of undestroyed shells of freshwater bivalves (Unio pictorum L. and Anodonta cygnea L.) together with animal bones. Salzmünde vessels and a typical Salzmünde ceramic drum assigned this feature to the Salzmünde phase. From this feature, a cattle bone was ${ }^{14} \mathrm{C}$ dated to $4460 \pm 40 \mathrm{BP}$ (KIA-41496) while an associated bivalve shell was dated to $6225 \pm 45$ BP (KIA-41497), indicating a local reservoir age of $\sim 1770 \mathrm{yr}$.

The large amount of freshwater shells found in Salzmünde features points to the potential contribution of aquatic food sources to human diet. Human bones of a Zauschwitz Salzmünde burial (no. 121) were ${ }^{14} \mathrm{C}$ dated on collagen to $6415 \pm 30 \mathrm{BP}\left(\mathrm{KIA}-42250 ; \delta^{13} \mathrm{C}=-19.6 \%\right.$ and $\delta^{15} \mathrm{~N}=$ $9.0 \%$ ) and those of a Salzmünde double grave (no. 103/104) dated to $5295 \pm 30 \mathrm{BP}$ (KIA-37858; $\delta^{13} \mathrm{C}=-20.0 \%$ and $\delta^{15} \mathrm{~N}=10.5 \%$ ) and $5295 \pm 35 \mathrm{BP}\left(\mathrm{KIA}-37859 ; \delta^{13} \mathrm{C}=-20.3 \%\right.$ and $\delta^{15} \mathrm{~N}=$ $9.2 \%$ ). Calibrated age ranges $(2 \sigma, 95.4 \%)$ are confined to the intervals 5471-5327 cal BC (KIA42250), 4235-4005 cal BC (KIA-37858), and 4236-4000 cal BC (KIA-37859). Though the age range for sample KIA-42250 is surprisingly old and warrants further investigation, a large reservoir effect is assumed, despite unremarkable stable isotope values, as Salzmünde pottery was used from 3600 to 2700 cal BC (Müller 2001).

Two live freshwater specimens (Z-01 and Z-02) of Anodonta anatina (duck mussel), a species also found in the archaeological site, were collected (Table 1) from the Weiße Elster River, in the immediate vicinity of the site. The lower valley of the Weiße Elster runs through tertiary (lignite, sand) and quaternary (mostly gravel, boulder clay and marl, loess) material. ${ }^{14} \mathrm{C}$ dates of paleochannel sediments and fossil soil horizons of the Weiße Elster floodplain show differences of up to 20,000 ${ }^{14} \mathrm{C}$ yr between various organic components and fractions of the same sample (Hiller et al. 2003). These differences may be attributed to reworked Tertiary lignite material (Hiller et al. 2003).

Lake Rosenfeld is a dammed lake located $\sim 5 \mathrm{~km}$ southeast of the city of Kiel. Rosenfeld is part of a large lake region in southeastern Schleswig-Holstein. Geologically, the region is characterized by a complex mix of sediments (till, outwash sands, and glaciolacustrine) deposited during the Weichselian and Saalian glaciations (Scheytt 1997). The single lacustrine live bivalve sample (R-01), of Unio tumidus, was collected from Lake Rosenfeld (Table 1).

\section{Analytical Methods}

To remove adhering dust and detrital carbonate as well as organic surface coating, bivalve shell samples were first cleaned with $30 \% \mathrm{H}_{2} \mathrm{O}_{2}$ in an ultrasonic bath, followed by a second cleaning step with $15 \% \mathrm{H}_{2} \mathrm{O}_{2}$ in an ultrasonic bath. Isotopic signals in bivalve shells vary along the major growth axis, reflecting varying environmental signals (Poulain et al. 2010). In order to obtain average isotopic signals, $\sim 5$-mm-wide sections were cut from the shell edge along the major growth axis. The sample was then milled into a fine powder and 2 aliquots were collected for ${ }^{14} \mathrm{C}$ and $\delta^{13} \mathrm{C}$ analysis. 
For carbonate ${ }^{14} \mathrm{C}$ measurement, sample $\mathrm{CO}_{2}$ is liberated from each sample with $100 \%$ phosphoric acid at $90{ }^{\circ} \mathrm{C}$. The carbon dioxide is collected in a sample bottle using liquid nitrogen. The sample $\mathrm{CO}_{2}$ is then reduced to graphite with $\mathrm{H}_{2}$ at $600{ }^{\circ} \mathrm{C}$ over $2 \mathrm{mg}$ of an iron catalyst. The iron/carbon mixture is pressed as a pellet into a target holder for accelerator mass spectrometry (AMS) measurement in a $3 \mathrm{MV}$ Tandetron from High Voltage Engineering Europa (HVEE) with a single cesium sputter ion source and a separator/recombinator for simultaneous injection of the 3 isotopic carbon beams (Nadeau et al. 1997, 1998). The ${ }^{14} \mathrm{C}$ concentration of the sample is measured by comparing the simultaneously collected ${ }^{14} \mathrm{C},{ }^{13} \mathrm{C}$, and ${ }^{12} \mathrm{C}$ beams of each sample with those of the oxalic acid II primary standard. For determination of the measuring uncertainty, both the counting statistics of the ${ }^{14} \mathrm{C}$ measurement and the variability of the 8-12 interval results that, together, make up 1 measurement are observed and the larger of the two is adopted as the measuring uncertainty (Nadeau et al. 1998, 2001).

Carbon isotopic composition $\left(\delta^{13} \mathrm{C}\right)$ of bivalve shells was determined for all samples at the LeibnizLaboratory for Radiometric Dating and Isotope Research (Kiel, Germany). Individual powder samples of bivalve carbonate were acidified in $100 \%$ phosphoric acid at a constant $75^{\circ} \mathrm{C}$ using an automated Kiel I (prototype) carbonate preparation device coupled to a Finnigan MAT 251 mass spectrometer. Replicate ${ }^{13} \mathrm{C}$ analyses of standards yielded a precision of $<0.05 \%$ for internal laboratory and NBS-19 (National Institute of Standards and Technology, NIST SRM 8544) standards.

Measurements of $\delta^{13} \mathrm{C}$ on bivalve tissue were performed at the stable isotope laboratory of the Museum für Naturkunde (Berlin, Germany). Stable isotope analysis and concentration measurements of carbon were performed with a Thermo Finnigan MAT V isotope ratio mass spectrometer, coupled to a Thermo Flash EA 1112 elemental analyzer via a Thermo Finnigan Conflo III interface. Stable isotope ratios are expressed in the conventional delta notation $\left(\delta^{13} \mathrm{C}\right)$ relative to VPDB (Vienna PeeDee belemnite standard). Standard deviation for repeated measurements of laboratory standard material (peptone) is generally better than $0.15 \%$. Standard deviations of concentration measurements of replicates of lab standard were $<3 \%$ of the concentration analyzed. A portion of bivalve tissue was washed, freeze-dried, and then combusted for ${ }^{14} \mathrm{C}$ dating. Combustion, reduction, and AMS measurements follow the Leibniz Laboratory standard procedures (Nadeau et al. 1998).

\section{RESULTS AND DISCUSSION}

Bivalve mollusks are filter feeders and obtain their food from both suspended (e.g. phytoplankton, bacteria) and particulate organic matter (Amouroux 1984; Bayne et al. 1993; Cranford and Hill 1999; Roditi et al. 2000; Vaughn and Hakenkamp 2001; Vuorio et al. 2007). The different bivalve tissues (gill, visceral mass, muscles, mantle, foot, gonads) are synthesized through the incorporation of metabolic carbon (Amouroux 1984; Roditi et al. 2000; Poulain et al. 2010). While bivalve shells derive their carbon primarily from the water dissolved inorganic carbon (DIC) pool, a significant portion of shell carbon is also derived from metabolic carbon, with the relative proportion being species-dependent (Gillikin et al. 2006, 2009; Franck et al. 2010; Poulain et al. 2010).

Organic carbon in aquatic reservoirs originates from terrestrial organic matter, in situ biological production, and from anthropogenic activities (Hope et al. 1994). A distinction between dissolved organic carbon (DOC) and suspended or particulate organic carbon (POC) is generally made on the basis of whether or not it passes through a $0.45-0.50 \mu \mathrm{m}$ filter (Hope et al. 1994). DOC consists of organic liquids, hydrocarbons, methane, and humic components (Geyh 2000). Meanwhile, dissolved inorganic carbon (DIC) occurs in ionic form as bicarbonate, carbonate, carbonic acid, or as dissolved gaseous carbon dioxide (Hope et al. 1994), and predominant species are determined by the 
$\mathrm{pH}$ regime. The amount of $\mathrm{CO}_{2}$ dissolved in the water depends on its partial pressure, which is determined by uptake from the atmosphere, photosynthesis, and from the oxidation of organic matter. Natural ${ }^{14} \mathrm{C}$ activity of DOC and DIC can differ significantly in both marine and freshwater contexts (e.g. Drimmie et al. 1991; McNichol et al. 1994; Geyh 2000).

${ }^{14} \mathrm{C}$ and $\delta^{13} \mathrm{C}$ results, both for bivalve tissue and shell, are listed in Table 3 and represented graphically in Figures 3 and 4 . The results indicate statistically non-significant tissue-shell ${ }^{14} \mathrm{C}$ age differences for Mytilus edulis marine bivalve species (K-01 to K-04), and significant ${ }^{14} \mathrm{C}$ age differences for freshwater samples, both in a lacustrine (R-01) and in a riverine (Z-01 and Z-02) environment.

Table 3 Radiocarbon $\left({ }^{14} \mathrm{C}\right)$ and stable carbon $\left(\delta^{13} \mathrm{C}\right)$ results for bivalve tissue and shell.

\begin{tabular}{llcccr}
\hline & $\begin{array}{l}\delta^{13} \mathrm{C} \text { tissue } \\
\text { (\%o VPDB) }\end{array}$ & $\begin{array}{l}\delta^{13} \mathrm{C} \text { shell } \\
(\% \text { VPDB) }\end{array}$ & $\begin{array}{l}\text { Tissue } \\
\text { conventional } \\
\text { age (yr BP) }\end{array}$ & $\begin{array}{l}\text { Shell } \\
\text { conventional } \\
\text { age (yr BP) }\end{array}$ & $\begin{array}{l}\text { Age } \\
\text { difference } \\
\text { (yr) }\end{array}$ \\
\hline K-01 (Mytilus edulis) & -22.11 & -1.44 & $290 \pm 30$ & $350 \pm 40$ & $60 \pm 50$ \\
K-02 (Mytilus edulis) & -22.62 & -1.11 & $260 \pm 30$ & $200 \pm 20$ & $-60 \pm 35$ \\
K-03 (Mytilus edulis) & -21.92 & -1.51 & $280 \pm 30$ & $275 \pm 20$ & $-5 \pm 35$ \\
K-04 (Mytilus edulis) & -22.27 & -0.60 & $315 \pm 25$ & $300 \pm 30$ & $-15 \pm 40$ \\
Z-01 (Anodonta anatina) & -30.64 & -15.20 & $1140 \pm 20$ & $1495 \pm 20$ & $355 \pm 30$ \\
Z-02 (Anodonta anatina) & -30.26 & -14.70 & $1010 \pm 20$ & $1195 \pm 20$ & $185 \pm 30$ \\
R-01 (Unio tumidus) & -28.48 & -7.94 & $575 \pm 20$ & $410 \pm 30$ & $-165 \pm 50$ \\
\hline
\end{tabular}

Gillikin et al. (2006) reported, in contrast with Tanaka et al. (1986), that $<10 \%$ shell carbon in Mytilus edulis originates from metabolic carbon, making this species sensitive to significant ${ }^{14} \mathrm{C}$ age differences between DOC/POC and DIC. No statistically significant differences are observed between the tissue ages of different Mytilus edulis specimens, indicating a well-mixed pool of organic matter. There are, however, significant differences between the specimens' shell ages, possibly associated with different amounts of metabolic carbon being incorporated into the shell. Conventional ${ }^{14} \mathrm{C}$ ages of Mytilus edulis shells range from 200 to $350 \mathrm{yr}$ BP. The reservoir age needs to be corrected for the atmospheric ${ }^{14} \mathrm{C}$ value at the time of collection. A simple estimation, which ignores variations in ${ }^{14} \mathrm{C}$ values during bivalve growth, was done by considering a ${ }^{14} \mathrm{C}$ pMC (percentage of modern carbon) value at time of collection of $\sim 104$ pMC (I Levin, personal communication). An age correction of $\sim 320 \mathrm{yr}$ gives for the Mytilus edulis shell samples reservoir ages between 520 and $670 \mathrm{yr}$, an interval that contains the average mollusk shell reservoir age of $560 \mathrm{yr}$ observed at Quern-Neukirchen (Table 2).

Comparative measurements of the oceanic ${ }^{14} \mathrm{C}$ signal in organic matter (POC or DOC) and DIC have been made previously (e.g. Williams and Druffel 1987; Druffel et al. 1992; Druffel and Bauer 2000). Oceanic DOC has long residence times and measurements revealed a ${ }^{14} \mathrm{C}$ age difference of over 3000 yr between DOC and DIC, with older DOC, at near surface waters in the North Atlantic Ocean (Druffel et al. 1992). However, POC ${ }^{14} \mathrm{C}$ ages were similar or slightly younger than DIC ages, indicating that a significant fraction had formed recently during photosynthetic fixation of DIC in surface waters (Druffel et al. 1992). POC ${ }^{14} \mathrm{C}$ enrichment over DOC has also been noted for coastal locations, though with a high degree of variability (Raymond and Bauer 2001).

Mytilus edulis specimens' tissue-shell age differences (Table 3, Figure 3) are in most cases non-significant with age overlaps within the sigma range, the exception being sample K-02 though only outside the $1 \sigma$ age overlap range by $10 \mathrm{yr}$. 
Marine samples of Mytilus edulis (Kiel Fjord)

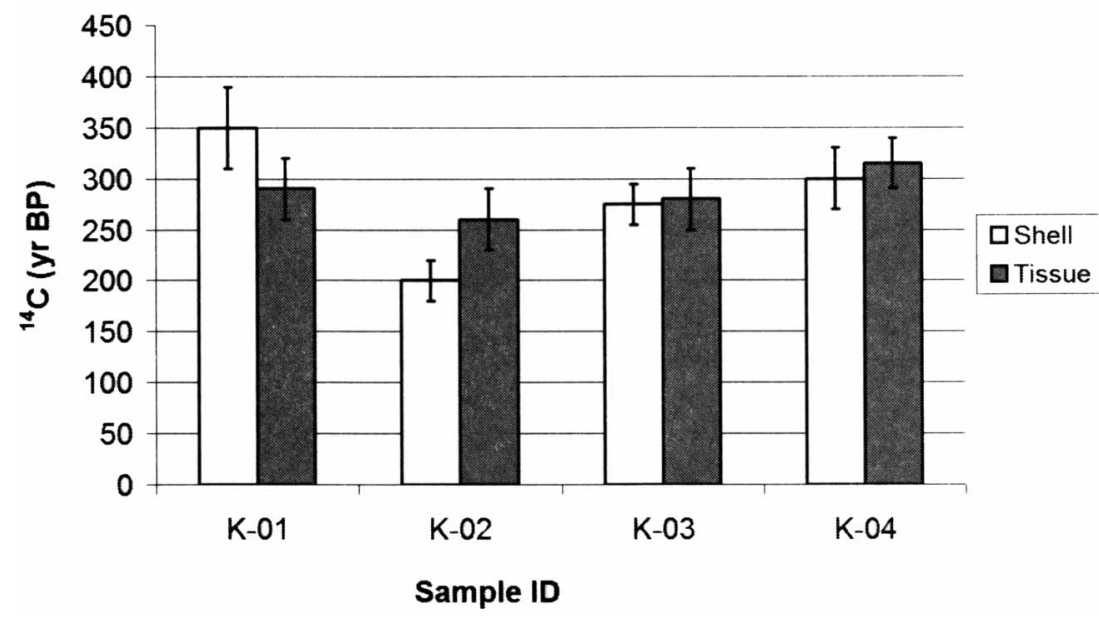

Figure $3{ }^{14} \mathrm{C}$ ages (Table 3) for modern Mytilus edulis bivalve, tissue and shell, collected from the Kiel Fjord.

The $\delta^{13} \mathrm{C}$ isotope composition of bivalve shells living in estuarine habitats constitutes a salinity proxy (Poulain et al. 2010), with the amount of respired $\mathrm{CO}_{2}$ in the skeleton approximated using balance equations that account for different carbon contributions (Gillikin et al. 2006). Tissue and shell $\delta^{13} \mathrm{C}$ results in Table 3 are, however, not statistically representative nor sufficiently variable to allow establishing a connection between different tissue-shell ages and $\delta^{13} \mathrm{C}$ values. For example, samples $\mathrm{K}-03$ and $\mathrm{K}-04$ present the lowest $(-1.51 \%)$ and the highest $(-0.60 \%) \delta^{13} \mathrm{C}$ shell values. In principle, these values could be used as a carbon source indicator through the comparison of $\delta^{13} \mathrm{C}$ reference values for dissolved atmospheric $\mathrm{CO}_{2}\left(\delta^{13} \mathrm{C}=-7\right.$ to $-9 \%$ ), limestone carbonates $\left(\delta^{13} \mathrm{C} \sim 0 \%\right.$ ), and organic-matter-derived $\mathrm{CO}_{2}\left(\delta^{13} \mathrm{C}=-25\right.$ to $-30 \%$ ). However, these samples present intermediate shell reservoir effect ages.

The results for the Kiel Fjord suggest a similar ${ }^{14} \mathrm{C}$ signal for DIC and POC, perhaps slightly older for POC in Kiel Bay. However, locations for which there is a greater terrestrial POC input and a less well-mixed environment, such as estuarine locations (Raymond and Bauer 2001), may introduce different reservoir ages. Species that incorporate variable fractions of POC or DOC may also exhibit variations in reservoir ages, e.g. deposit feeders when compared with filter feeders (Hogg and Higham 1998).

The 2 riverine bivalve specimens (Z-01 and Z-02), collected only $10 \mathrm{~m}$ from each other, show significant differences in ${ }^{14} \mathrm{C}$ ages in both shell and tissue (Table 3, Figure 4). This result is in accordance with previous results that show high and variable ${ }^{14} \mathrm{C}$ deficiencies in riverine bivalve shells (e.g. Keith and Anderson 1963; Veinott and Cornett 1998). Freshwater bivalve mollusks of the Unioid family assimilate a high percentage (up to 35\%) of metabolic carbon into their shells (Gillikin et al. 2009). In natural waters, DOC can contribute a high percentage of the metabolic carbon demand of freshwater mussels (e.g. Roditi et al. 2000). The very significant differences in shell-tissue age (Table 3) for the Zauschwitz bivalves indicate a higher depletion in ${ }^{14} \mathrm{C}$ for DIC than for water organic matter (DOC and POC mix).

${ }^{14} \mathrm{C}$ dates from soil sediments of the Weiße Elster floodplain show the presence of reworked mobile old organic fractions, up to $20,000 \mathrm{yr}$ BP (Hiller et al. 2003). However, the study undertaken by Ray- 
mond and Bauer (2001) indicated that, although variable, in over $70 \%$ of the cases studied riverine DOC presented ${ }^{14} \mathrm{C}$ ages younger than POC. Solubilized DOC is generally exported to rivers from ${ }^{14} \mathrm{C}$-enriched topsoil material (Raymond and Bauer 2001). In contrast, the ${ }^{14} \mathrm{C}$ signal of riverine POC is significantly depleted with respect to current atmospheric values with ages reaching thousands of years, as it originates from old soil horizons, sedimentary fossil, sorbed petroleum and petroleum byproducts, and sewage sludge (Raymond and Bauer 2001). $\delta^{13} \mathrm{C}$ Anodonta anatina tissue values near $-30 \%$ are consistent with organic terrestrial food sources (Keith and Anderson 1963).

Shell reservoir ages, corrected for ${ }^{14} \mathrm{C}$ atmospheric content during the year of collection, are in the order of $1500 \mathrm{yr}(\mathrm{Z}-02)$ and $1800 \mathrm{yr}(\mathrm{Z}-01)$. The latter value is close to the reference value of $1770 \mathrm{yr}$ determined from the archaeological shell deposit at Zauschwitz (see text above).

Shell $\delta^{13} \mathrm{C}$ values were $-15.20 \%$ for Z-01 and $-14.70 \%$ for the larger Z-02 (Table 3). Compared with sample Z-01, a higher $\delta^{13} \mathrm{C}$ shell value for sample Z-02, its lower shell reservoir age (probable larger incorporation of DOC), and its smaller difference between shell and tissue ${ }^{14} \mathrm{C}$ indicate consistency with the results obtained by Gillikin et al. (2009). Gillikin et al. (2009) established a linear dependence between the amount of metabolic carbon incorporated into Unioid shells and shell length. This ontogenic effect, verified also for marine species (e.g. Lorrain et al. 2004), alerts for the variability of reservoir effects in freshwater bivalves, and the need for a representative sampling from the archaeological record. A shell height-based sampling is recommended, specifically one that includes young and old specimens. Also, tissue reservoir age can also be estimated by sampling the shell's edge of older specimens as it will probably approximate the tissue reservoir age during time of consumption, given that bivalve tissue presents a high turnover rate (Poulain et al. 2010). Shell sampling should always include several specimens of different species given the strong local variability, as illustrated by the large tissue age difference (over $100 \mathrm{yr}$ ) between the 2 Zauschwitz specimens in spite of their close collection proximity.

Freshwater bivalve samples (Rosenfeld and Zauschwitz)

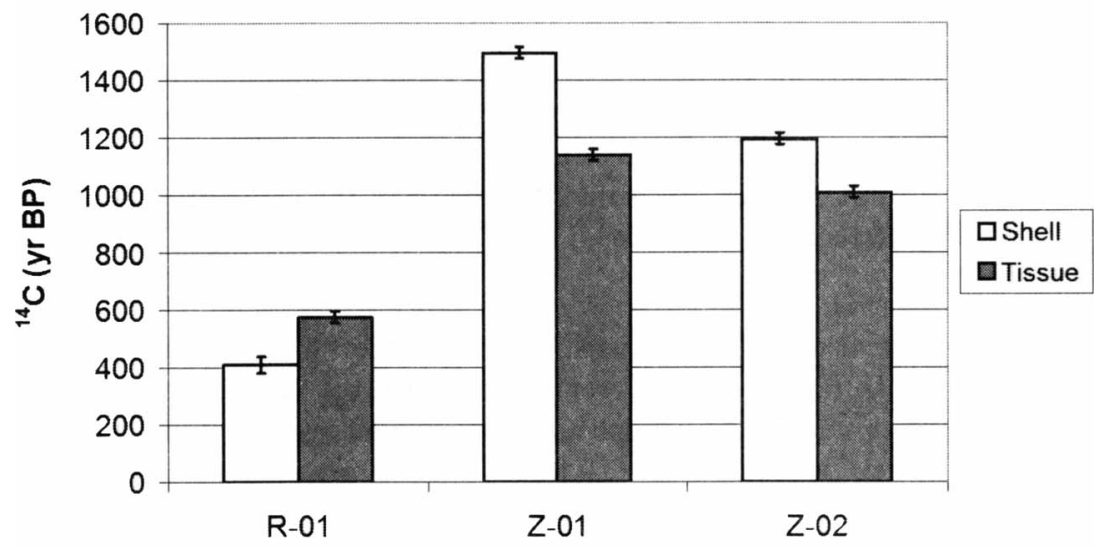

Sample ID

Figure $4{ }^{14} \mathrm{C}$ ages (from Table 3) for modern freshwater bivalve samples, tissue and shell, collected from Lake Rosenfeld (Unio tumidus) and from the Weiße Elster river (Anodonta anatina) near the site of Zauschwitz. 
The only specimen (R-01), of Unio tumidus from a lacustrine location (Rosenfeld), presents an older tissue than shell age by over $150 \mathrm{yr}$ (Table 3, Figure 4). The sample's $\delta^{13} \mathrm{C}$ tissue value $(-28.48 \%$ o approaches terrestrial organic values, while its $\delta^{13} \mathrm{C}$ shell composition $(-7.94 \%$ ) is intermediate between typical marine and river fluvial values, presenting also an intermediate shell reservoir age, consistent with known results from lacustrine environments (Keith and Anderson 1963; Rea and Colman 1995). Keith and Anderson (1963) hypothesized that more depleted $\delta^{13} \mathrm{C}$ values in lacustrine bivalve shells reflect the incorporation into DIC of $\mathrm{CO}_{2}$ produced by fermentation of bottom muds that have $\delta^{13} \mathrm{C}$ values of approximately $-5 \%$. The fact that the Rosenfeld sample presents an older tissue than shell ${ }^{14} \mathrm{C}$ age may be explained by a different hypothesis. Besides POC originating from old terrestrial soil horizons, it is also likely that organic matter in lakes is characterized by higher residence times when compared with rivers.

\section{CONCLUSIONS}

The results obtained for riverine and lacustrine shells show large and variable freshwater reservoir effects, contrasting with smaller and less variable reservoir effects in marine shells. Significant differences in the ${ }^{14} \mathrm{C}$ of DIC, POC, and DOC result in significant age differences between bivalves' tissue and shell. Tissue-shell ${ }^{14} \mathrm{C}$ differences will depend on the type and amount of organic matter consumed (POC vs. DOC), on the amount of metabolic carbon incorporated into bivalve shell, and on the degree of mixing of available food sources. Metabolic preferences of bivalves are speciesand growth-stage-dependent.

Well-mixed marine locations, for which there is a similar ${ }^{14} \mathrm{C}$ signal in DIC and POC, result in small age differences between bivalve tissue and shell, provided that the amount of metabolized DOC is also small. This is most likely the case in Kiel Bay with no significant ${ }^{14} \mathrm{C}$ age differences for tissue and shell of Mytilus edulis specimens. This result also suggests the validity of using a 560-yr reservoir age for the site of Quern-Neukirchen as established previously from the archaeological record.

In freshwater, there is extensive local variability in ${ }^{14} \mathrm{C}$ values for DIC, POC, and DOC. Freshwater bivalve specimens from Zauschwitz and Rosenfeld presented significant ${ }^{14} \mathrm{C}$ differences between bivalve tissue and shell. This observation implies that the use of archaeological bivalve shells in a freshwater context, as a means of establishing local reservoir age, is only advisable when accompanied by knowledge of ${ }^{14} \mathrm{C}$ tissue vs. shell age differences. Bivalve sampling should also be representative and include different edible species, and several specimens from each species. Thus, though the archaeologically established reservoir age of $1770 \mathrm{yr}$ for Zauschwitz (in a single shell sample) is in close proximity with 1 modern shell measurement $(1800 \mathrm{yr})$, the large differences with a second sample (1500 yr), and differences in tissue-shell ages (over $100 \mathrm{yr}$ ), suggest caution in defining a single local reservoir age.

These results illustrate the need for further investigation into the variability of reservoir effects and tissue-shell reservoir age differences of different aquatic species. This is particularly relevant in freshwater contexts. Future studies should also address reservoir age variability in tissue of higher trophic level species, namely in fish species that represented an important food source for different ancient populations.

\section{ACKNOWLEDGMENTS}

We thank Shafiqa Shafaq, Nicole Möckel, and Angelika Oriwall for their assistance in sample preparation. The authors wish to acknowledge the help of Michael Zettler who identified the freshwater bivalve species. A special thanks goes to Dr John Meadows, for his insightful feedback and English 
revision. Research funding is provided by the German Research Foundation (Deutsche Forschungsgemeinschaft) within the frame of the Priority Program SPP 1400 and the Graduate School "Human Development in Landscapes" of the German Excellence Initiative.

\section{REFERENCES}

Amouroux JM. 1984. Preliminary study on the consumption of dissolved organic matter (exudates) of bacteria and phytoplankton by the marine bivalve Venus verrucosa. Marine Biology 82(2):109-12.

Arawomo GAO. 1980. The food of juvenile trout, Salmo trutta L., in Loch Leven, Kinross, Scotland. Hydrobiologia 75(1):49-56.

Ascough PL, Cook GT, Dugmore AJ, Barber J, Higney E, Scott EM. 2004. Holocene variations in the Scottish marine radiocarbon reservoir effect. Radiocarbon 46(2):611-20.

Ascough P, Cook G, Dugmore A. 2005. Methodological approaches to determining the marine radiocarbon reservoir effect. Progress in Physical Geography 29(4):532-47.

Ascough PL, Cook GT, Dugmore AJ, Scott EM. 2007. The North Atlantic marine reservoir effect in the early Holocene: implications for defining and understanding MRE values. Nuclear Instruments and Methods in Physics Research B 259(1):438-47.

Ascough PL, Cook G, Church MJ, Dunbar E, Einarsson A, Dugmore AJ, Perdikaris S, Hastie H, Frioriksson A, Gestsdottir H. 2010. Temporal and spatial variations in freshwater ${ }^{14} \mathrm{C}$ reservoir effects: Lake Mývatn, northern Iceland. Radiocarbon 52(2-3):1098-12.

Ascough PL, Cook GT, Hastie H, Dunbar E, Church MJ, Einarsson Á, McGovern TH, Dugmore AJ. 2011. An Icelandic freshwater radiocarbon reservoir effect: implications for lacustrine ${ }^{14} \mathrm{C}$ chronologies. The Holocene 21(7):1073-80.

Balbo A, Madella M, Godino IB, Álvarez M. 2011. Shell midden research: an interdisciplinary agenda for the quaternary and social sciences. Quaternary International 239(1-2): 147-52.

Bayne BL, Iglesias JIP, Hawkins AJS, Navarro E, Heral M, Deslous-Paoli JM. 1993. Feeding behaviour of the mussel, Mytilus edulis: responses to variations in quantity and organic content of the seston. Journal of the Marine Biological Association of the United Kingdom 73:813-29.

Cage AG, Heinemeier J, Austin WEN. 2006. Marine radiocarbon reservoir ages in Scottish coastal and fjordic waters. Radiocarbon 48(1):31-43.

Coblenz W, Fritzsche C. 1980. Kleinstkindbestattung in einer reich ausgestatteten Salzmünder Grube mit Muschelschichten von Zauschwitz, Kr. Borna. Ausgrabungen und Funde 25:5-17.

Cook GT, Bonsall C, Hedges REM, McSweeney K, Boroneant V, Pettitt PB. 2001. A freshwater diet-derived ${ }^{14} \mathrm{C}$ reservoir effect at the Stone Age sites in the Iron Gates Gorge. Radiocarbon 43(2):453-60.
Cranford PJ, Hill PS. 1999. Seasonal variation in food utilization by the suspension-feeding bivalve molluscs Mytilus edulis and Placopecten magellanicus. Marine Ecology Progress Series 190:223-39.

Culleton BJ. 2006. Implications of a freshwater radiocarbon reservoir correction for the timing of late Holocene settlement of the Elk Hills, Kern County, California. Journal of Archaeological Science 33(9): 1331-9.

Drimmie RJ, Aravena R, Wassenaar LI, Fritz P, Hendry MJ, Hut G. 1991. Radiocarbon and stable isotopes in water and dissolved constituents, Milk River aquifer, Alberta, Canada. Applied Geochemistry 6(4):381-92.

Druffel ERM, Williams PM, Bauer JE, Ertel JR. 1992. Cycling of dissolved and particulate organic matter in the open ocean. Geophysical Research Letters 97(C10):15,639-59.

Druffel ERM, Bauer JE. 2000. Radiocarbon distributions in Southern Ocean dissolved and particulate organic matter. Geophysical Research Letters 27(10):1495-8.

Dumond D, Griffin D. 2002. Measurements of the marine reservoir effect on radiocarbon ages in the eastern Bering Sea. Arctic 55(1):77-86.

Fischer A, Olsen J, Richards M, Heinemeier J, Sveinbjörnsdóttir ÁE, Bennike P. 2007. Coast-inland mobility and diet in the Danish Mesolithic and Neolithic: evidence from stable isotope values of humans and dogs. Journal of Archaeological Science 34(12): 2125-50.

Franck L, Laurent E, de Marc R, Stephane P, Maurice R. 2010. Influence of food supply on the $\delta^{13} \mathrm{C}$ signature of mollusc shells: implications for palaeoenvironmental reconstitutions. Geo-Marine Letters 30(1):23-34.

Geyh M. 2000. An overview of ${ }^{14} \mathrm{C}$ analysis in the study of groundwater. Radiocarbon 42(1):99-114.

Geyh M, Schotterer U, Grosjean M. 1998. Temporal changes of the ${ }^{14} \mathrm{C}$ reservoir effect in lakes. Radiocarbon 40(2):921-31.

Gillespie R, Fink D, Petchey F, Jacobsen G. 2009. Murray-Darling basin freshwater shells: riverine reservoir effect. Archaeology in Oceania 44(2):107-11.

Gillikin DP, Lorrain A, Bouillon S, Willenz P, Dehairs F. 2006. Stable carbon isotopic composition of Mytilus edulis shells: relation to metabolism, salinity, $\delta^{13} \mathrm{C}$ DIC and phytoplankton. Organic Geochemistry 37(10):1371-82.

Gillikin DP, Hutchinson KA, Kumai Y. 2009. Ontogenic increase of metabolic carbon in freshwater mussel shells (Pyganodon cataracta). Journal of Geophysical Research 114: G01007, doi:10.1029/2008JG000829.

Gordon JE, Harkness DD. 1992. Magnitude and geo- 
graphic variation of the radiocarbon content in Antarctic marine life: implications for reservoir corrections in radiocarbon dating. Quaternary Science Reviews 11(7-8):697-708.

Gutiérrez-Zugasti I, Andersen SH, Araújo AC, Dupont C, Milner N, Monge-Soares AM. 2011. Shell midden research in Atlantic Europe: state of the art, research problems and perspectives for the future. Quaternary International 239(1-2):70-85.

Habu J, Matsui A, Yamamoto N, Kanno T. 2011. Shell midden archaeology in Japan: aquatic food acquisition and long-term change in the Jomon culture. Quaternary International 239(1-2):19-27.

Hall BL, Henderson GM. 2001. Use of uranium-thorium dating to determine past ${ }^{14} \mathrm{C}$ reservoir effects in lakes: examples from Antarctica. Earth and Planetary Science Letters 193(3-4):565-77.

Hiller A, Tinapp C, Grootes PM, Nadeau MJ. 2003. Ungewöhnliche Probleme bei der ${ }^{14} \mathrm{C}$-Datierung organischer Komponenten und Fraktionen fluviatiler Sedimente aus der Aue der Weißen Elster bei Leipzig. Quaternary Science Journal 52(1):4-12.

Hogg AG, Higham TFG. $1998 .{ }^{14} \mathrm{C}$ dating of modern marine and estuarine shellfish. Radiocarbon 40(2):97584.

Hope D, Billett MF, Cresser MS. 1994. A review of the export of carbon in river water: fluxes and processes. Environmental Pollution 84(3):301-24.

Jerardino A. 1998. Excavations at Panchos Kitchen Midden, western Cape Coast, South Africa: further observations into the Megamidden period. The South African Archaeological Bulletin 53(167):16-25.

Kallio H. 2006. The evolution of the Baltic Sea - changing shorelines and unique coasts. In: Schmidt-Thome $\mathrm{P}$, editor. Sea Level Change Affecting the Spatial Development of the Baltic Sea Region. Helsinki: Geological Survey of Finland. p 17-21.

Keith ML, Anderson GM. 1963. Radiocarbon dating: fictitious results with mollusk shells. Science 141(3581): 634-7.

Landmeyer JE, Stone PA. 1995. Radiocarbon and $\delta^{13} \mathrm{C}$ values related to ground-water recharge and mixing. Ground Water 33(2):227-34.

Lanting JN, van der Plicht J. 1998. Reservoir effects and apparent ${ }^{14} \mathrm{C}$-ages. Journal of Irish Archaeology 9: 151-65.

Levin I, Münnich KO, Weiss W. 1980. The effect of anthropogenic $\mathrm{CO}_{2}$ and ${ }^{14} \mathrm{C}$ sources on the distribution of ${ }^{14} \mathrm{C}$ in the atmosphere. Radiocarbon 22(2):379-91.

Levin I, Hesshaimer V. 2000. Radiocarbon-a unique tracer of global carbon cycle dynamics. Radiocarbon 42(1):69-80.

Lillie M, Budd C, Potekhina I, Hedges R. 2009. The radiocarbon reservoir effect: new evidence from the cemeteries of the middle and lower Dnieper basin, Ukraine. Journal of Archaeological Science 36(2): 256-64.
Lorrain A, Paulet Y-M, Chauvaud L, Dunbar R, Mucciarone $\mathrm{D}$, Fontugne $M .2004$. $\delta^{13} \mathrm{C}$ variation in scallop shells: increasing metabolic carbon contribution with body size? Geochimica et Cosmochimica Acta 68(17): 3509-19.

McNichol AP, Osborne EA, Gagnon AR, Fry B, Jones GA. 1994. TIC, TOC, DIC, DOC, PIC, POC - unique aspects in the preparation of oceanographic samples for ${ }^{14} \mathrm{C}$-AMS. Nuclear Instruments and Methods in Physics Research B 92(1-4):162-5.

Müller J. 2001. Soziochronologische Studien zum Jungund Spätneolithikum im Mittelelbe-Saale-Gebiet (4100-2700v.Chr). Eine sozialhistorische Interpretation prähistorischer Quellen. Rahden/Westf.

Nadeau MJ, Schleicher M, Grootes PM, Erlenkeuser H, Gottdang A, Mous DJW, Sarnthein JM, Willkomm H. 1997. The Leibniz-Labor AMS facility at the Christian-Albrechts-University, Kiel, Germany. Nuclear Instruments and Methods in Physics Research B 123(1-4):22-30.

Nadeau M-J, Grootes PM, Schleicher M, Hasselberg P, Rieck A, Bitterling M. 1998. Sample throughput and data quality at the Leibniz-Labor AMS facility. Radiocarbon 40(1):239-46.

Nadeau MJ, Grootes PM, Voelker A, Bruhn F, Duhr A, Oriwall A. 2001. Carbonate ${ }^{14} \mathrm{C}$ background: Does it have multiple personalities? Radiocarbon 43(2A): 169-76.

Naito YI, Honch NV, Chikaraishi Y, Ohkouchi N, Yoneda M. 2010. Quantitative evaluation of marine protein contribution in ancient diets based on nitrogen isotope ratios of individual amino acids in bone collagen: an investigation at the Kitakogane Jomon site. American Journal of Physical Anthropology 143(1):31-40.

Nie HW. 1982. A note on the significance of larger bivalve molluscs (Anodonta spp. and Dreissena sp.) in the food of the eel (Anguilla anguilla) in Tjeukemeer. Hydrobiologia 95:307-10.

Olsen J, Heinemeier J, Lübke H, Lüth F, Terberger T. 2010. Dietary habits and freshwater reservoir effects in bones from a Neolithic NE German cemetery. $R a$ diocarbon 52(2):635-44.

Olsson IU. 1980. Radiocarbon dating of material from different reservoirs. In: Suess HE, Berger R, editors. Radiocarbon Dating. Los Angeles: University of California Los Angeles Press. p 613-8.

Parmalee PW, Klippel WE. 1974. Freshwater mussels as a prehistoric food resource. American Antiquity 39(3): 421-34.

Poulain C, Lorrain A, Mas R, Gillikin DP, Dehairs F, Robert R, Paulet Y-M. 2010. Experimental shift of diet and DIC stable carbon isotopes: influence on shell $\delta^{13} \mathrm{C}$ values in the Manila clam Ruditapes philippinarum. Chemical Geology 272(1-4):75-82.

Raymond PA, Bauer JE. 2001. Use of ${ }^{14} \mathrm{C}$ and ${ }^{13} \mathrm{C}$ natural abundances for evaluating riverine, estuarine, and coastal DOC and POC sources and cycling: a review 
and synthesis. Organic Geochemistry 32(4):469-85.

Rea DK, Colman SM. 1995. Radiocarbon ages of prebomb clams and the hard-water effect in Lakes Michigan and Huron. Journal of Paleolimnology 14(1):8991.

Roditi HA, Fisher NS, Sanudo-Wilhelmy SA. 2000. Uptake of dissolved organic carbon and trace elements by zebra mussels. Nature 407(6800):78-80.

Roosevelt AC, Housley RA, Da Silveira MI, Maranca S, Johnson R. 1991. Eighth millennium pottery from a prehistoric shell midden in the Brazilian Amazon. Science 254(5038): 1621-4.

Scheytt T. 1997. Seasonal variations in groundwater chemistry near Lake Belau, Schleswig-Holstein, northern Germany. Hydrogeology Journal 5:86-95.

Schmölcke U, Endtmann E, Klooss S, Meyer M, Michaelis D, Rickert B-H, Rößler D. 2006. Changes of sea level, landscape and culture: a review of the southwestern Baltic area between 8800 and 4000 BC. Palaeogeography, Palaeoclimatology, Palaeoecology 240(3-4):423-38.

Smith AB, Sadr K, Gribble J, Yates R. 1991. Excavations in the south-western Cape, South Africa, and the archaeological identity of prehistoric hunter-gatherers within the last 2000 years. The South African Archaeological Bulletin 46(154):71-91.

Tanaka N, Monaghan MC, Rye DM. 1986. Contribution of metabolic carbon to mollusc and barnacle shell car- bonate. Nature 320(6062):520-3.

Vaughn CC, Hakenkamp CC. 2001. The functional role of burrowing bivalves in freshwater ecosystems. Freshwater Biology 46(11):1431-46.

Veinott GI, Cornett RJ. 1998. Carbon isotopic disequilibrium in the shell of the freshwater mussel Elliptio complanata. Applied Geochemistry 13(1):49-57.

Vuorio K, Tarvainen M, Sarvala J. 2007. Unionid mussels as stable isotope baseline indicators for long-lived secondary consumers in pelagic food web comparisons. Fundamental and Applied Limnology 169(9): 237-45.

Waselkov GA. 1987. Shellfish gathering and shell midden archaeology. Advances in Archaeological Method and Theory 10:93-210.

Williams PM, Druffel ERM. 1987. Radiocarbon in dissolved organic matter in the central North Pacific Ocean. Nature 330(6145):246-8.

Yoneda M, Shibata Y, Morita M, Hirota M, Suzuki R, Kazuhiro U, Ohshima N, Dodo Y. 2004. Interspecies comparison of marine reservoir ages at the Kitakogane shell midden, Hokkaido, Japan. Nuclear Instruments and Methods in Physics Research B 223-224:376-81.

Zhou A, Chen F, Wang Z, Yang M, Qiang M, Zhang J. 2009. Temporal change of radiocarbon reservoir effect in Sugan Lake, northwest China during the late Holocene. Radiocarbon 51(2):529-35. 